\title{
Africa as a Continent of Disasters and Crises: An Analysis of the Development Challenges and the Way Forward
}

\author{
Grace Lubaale \\ Department of Teacher Education and Development Studies, Kyambogo University, Uganda
}

Copyright (C) 2015 by authors, all rights reserved. Authors agree that this article remains permanently open access under the terms of the Creative Commons Attribution License 4.0 International License.

\begin{abstract}
Africa is neither poor nor developing, it is impoverished. Africa has a lot of material and human resources but for centuries, it has been forced to provide resources to the so-called "developed" world. This researched paper attempts to unravel the underlying factors for the perpetual disasters and crises in such a rich continent. The paper reveals that they are not a natural phenomenon, but social, economic and political constructs rooted in the erosion, denial and in some cases suppression of African cultures, resources and humanity. They are largely external but internally African's are not blameless. The paper concludes that Africa has enough resources to deal with her challenges provided the historical distortions that have caused disasters and crises in Africa are dealt with legally and ethically. And also recommends deconstructions of these social, economic and political constructs taking high regard of appropriate solutions from Africans because there can be no meaningful development outside one's culture.
\end{abstract}

Keywords Africa, Disasters, Development, Challenges, Opportunities

\section{Introduction}

Africa is $30,300,000$ square kilometers thus the $2^{\text {nd }}$ largest continent to Asia in size. It is characterized by diversity and comprises 56 states (Minara Chamber of Commerce, 2015), 7 Islands, 16 land locked states and 33 coastal nations. Forty (40) out of 56 states (about 71\%) have access to or are surrounded by major oceans indicative of great economic implications. Africa has many potential resources for development like: vast fertile land which is self-renewing in many parts. Many lakes and their products like water, fish, and rainfall formation, with Lake Victoria being 68,800 square kilometers thus being the $2^{\text {nd }}$ biggest lake in the world. Equally are rivers and their products with river Nile; 6,650 $\mathrm{km}$ long (World Atlas, 2015). There are varied natural features like mountains, rift valleys, with high implications of tourism and many forests, with the Congo as 2 nd largest to
Amazon in the world. There are also several foods of different types and high nutritional value, medicinal plants, and animals as well as high bio-diversity and favorable climate.

Many of the minerals of great economic value in the world are found in Africa like Morocco has more than 50\% of world phosphate reserves; South Africa is one of the countries in the world with large reserves of the scarcest and most precious metals, the Platinum-Group Metals (PGM) and these include platinum, palladium, rhodium, ruthenium, osmium and iridium. Africa has about $97 \%$ of world chromium reserves, $13 \%$ of copper, vast amounts of bauxite, nickel, lead and some uranium (Democratic Republic of Congo (D.R.C) and Mauritania). It has about $20 \%$ of hydroelectric potential; consider health, economic and environmental benefits. Africa produces about $70 \%$ of cocoa, $66 \%$ of coffee, $50 \%$ of palm oil and $20 \%$ of petroleum traded in the world (Kanyandogo, 2002).

Such is a rich continent, which is described as the continent of disasters and crises, which is absurd! In this paper, I will establish the causes and effects, which are external and internal simultaneously of disasters and crises together because they mean almost the same thing: catastrophe and then provide a conclusion and recommendations for a better Africa.

\section{Development Challenges}

Africa lost over 50 million people during slave trade who would have increased its population and productivity but went to develop the western world. By 1517, the Boers were already in South Africa. Since then, many came to Africa under the disguise of doing trade where Africans completely lost as their resources like minerals, people, and crops were being siphoned to Europe in exchange for small beads and old guns. During the partition and scramble for Africa in the $19^{\text {th }}$ century, economic potential of Africa was the greatest cause hence the coming of Europeans who exploited the resources of Africa (Rodney, 1972; Kiirya, 1996).

During colonialism, the situation worsened more with the 
justification that they were protecting Africans, civilizing them, and they were their colonial masters. Thus, they took the resources in pretext of protecting them, hence a big loss. A case in point is in Egypt, the British took over the country in 1882 to recover the debts Khadive Ishmail had failed to pay. These debts within 5 years were already recovered but they stayed in Egypt exploiting the country until 1922 (Rodney, 1972; Kiirya, 1996) and Egypt has never recovered from such exploitation.

After colonialism, exploitation of Africa has intensified in the postcolonial era. The international economic system has enormously impoverished and underdeveloped Africa. The International System serves to keep the North rich at the expense of the poor and powerless South (Africa inclusive). Africa serves as the source for cheap labour, agricultural, minerals and other raw materials for the North as well as its captive market. The North charges the South (Africa) high prices for its goods (imports to Africa) while paying Africa low prices for her goods (exports) and often fluctuating while theirs is constant. Attempts of the South (Africa) to industrialize in order to achieve self-reliance are failed by the North in form of trade barriers; control of capital goods; technology and finances besides divide and rule in the development process of Africa. The resultant effect is the "vicious circle of poverty" i.e. persistent poverty due to low incomes, which lead to low savings, low investments, low capital accumulation and then low incomes (Tayebwa, 1992, Todaro 2000, Okiira et le, 2001). Secondly such exploitation has led to great economic loss and continued dependence of Africa at the gain of the North despite her resources. A case in point is the North received net transfers of $\$ 163$ billion dollars in debt-related payments in the period 1984-1988 and a net transfer of resources amounting to $\$ 83$ billion in transactions involving 18 non-oil commodities between 1981-1986 (Kinoti (Ed;1997), Indeed no doubt, Africa is impoverished by the Western world.

External influences typical of colonialism, neo colonialism and now new colonialism in the development process of Africa has created more disasters and crises than it has solved evidenced in poverty and wars. I will sight two examples to illustrate this external influence domination effects.

One is the Modernization theory of development, which was introduced in Africa from the developed world without detailed consultation. In this theory, the developed countries introduced their methods of work and approaches to development in Africa, which distorted African steady development. Africans did not resist but rather mechanically imitated (copied) western methods which have failed and adversely led to poverty, inequalities, "killed" African innovations, distorted systems of work, Euro-centric lifestyles, methods of work, and thinking which is not sustainable, increased inferiority of Africans and continued dependence, which is in their interests and benefit (Lubaale, 2011; 2012).

Two is the Structural Adjustment Programmes (SAPs) from the International Monetary Fund (IMF) and World
Bank in directing the economic development of Third world countries (Africa). These programmes/policies like liberalization, privatization, increased interest rates and Bank rates, mechanization of Agriculture, retrenchment of civil servants and so on have led to more poverty, crises at home and in the country, inequalities, low production, environmental degradation, increased debts and continued dependency on the developed world certainly which is in their interests at the cost of Africa.

Wars and conflicts are many in Africa and indeed constitute the description of Africa as a continent of disasters and crises. The causes are external and internal. These interstate wars and conflicts are historical in Africa for domination, superiority, and conquest like Buganda and Bunyoro in Uganda, Mandinka Empire and neighboring states in West Africa. Their effects on development, natural resources, and poverty was grieve but containable in African setting. However, during the partition and scramble for Africa in the last decades of the $19^{\text {th }}$ century and early decades of the $20^{\text {th }}$ century when Africans resisted colonialism for the sake of their independence, many people died, natural resources destroyed, low economic progress and consequently massive exploitation by the whites after defeating Africans and conquering Africa by 1914. Examples include: The Shona-Ndeblele uprising (1896-97) in Central Africa; Maji Maji rebellion (1905-07) in East Africa; Temne-Mende war of 1898 in West Africa and Bambata rebellion (1906-07) in South Africa among others (Rodney, 1972; Kiirya, 1996).

Shortly after conquest, in the middle of the $20^{\text {th }}$ century, Africans rose up again against colonialists in order to secure their independence. Such rising for independence was not a walk over but a struggle in form of rebellions, wars, and revolutions. For example, the Mau Mau rebellion in Kenya 1952-55, Algerian war of independence 1954-1962, liberation wars in Angola, and Guinea Bissau, civil wars in Sudan and the Egyptian revolution of 1952, among others, all struggling to attain nationalism and liberalism, led to poverty, destruction of property, natural resources and life, suspicion and counter suspicion and continued dependence on the North.

Wars did not end at attaining independence. In the post colonial era, wars of liberation like in Uganda 1980-1986 led by Mr. Yoweri Museveni, Sudan 1980 up to 2012 led by Dr John Garanga (RIP) and the SPLA eventually which have led to breakaway and formation of South Sudan state from Sudan, Zaire now D.R.C led by Mr. Kabila (RIP) which removed the dictatorship of H.E Mobutu, and Mr. Savimbi (RIP) of Angola who fought dictatorship in the country till his death. Military coups in Africa like the 1971 in Uganda led by Gen. Amin Dada which removed H.E Milton Obote, (25 $5^{\text {th }}$ January 1971); in Ghana which led to the down fall of H.E Kwame Nkrumah on $24^{\text {th }}$ February 1966 among others. These wars have led to internal differences, suspicions, tribalism, corruption and regionalism which have culminate into poverty, destruction of natural resources, life, property, and means of production hence crises and disasters in Africa. 
Bad governance in Africa indeed constitutes one of the major historical and present development challenges on the continent. Governance is the process of decision making and the process of implementing or not implementing (action or inaction) of the decisions made for the good of the people under governance. Governance constitutes of; participation, rule of the law, transparency, responsiveness, consensus oriented, equity and inclusiveness, effectiveness and efficiency, and accountability. Bad governance, therefore, is the act of doing contrary to the definition and procedures of governance. It is prevalent in Africa and highly responsible for the catastrophes in Africa. Here I will sight to two examples: corruption and tribalism which are directly due to bad governance.

Corruption refers to any behaviour contrary to formal duties, obligations, agreements and rules/regulations for private interests (Lubaale, 2012). This corruption cancer has created grave social-economic and political consequences mostly negative on the spheres of life and our continent Africa. For example: Nigeria is one of the largest ten or so producers of oil in the world, accounting for about $10 \%$ of U.S.A oil imports, but Nigeria is one of the 21 poorest nations in terms of GNP per capital. Wealth distribution is unfair and income inequalities are grave with many millionaires and multimillionaires overnight because of corruption alongside very indigent people. Zaire, under Mobutu and the current D.R.C has many natural resources particularly minerals, waters, lands and forests but is devastated economically, socially and politically because of corruption and bad governance. In Kenya, the economy was doing very well after independence, but soon got engulfed in corruption particularly in public services, parastatals and government. Now the economy is grappling with widening inequalities between the people and regions that are so grave evidenced by several commissions of enquiry that have been set up by the Government and the International community (Kinoti, 1997). In Uganda, the Inspector General of Government (IGG) Mr. Jotham Tumwesigye in 1989 while opening a workshop on public awareness against corruption, highlighting its gravity in the country had this to say:

We must wakeup to the fact that corruption is very dangerous to our country. It retards the social and economic development of our nation. For example we have always heard salaries of employees particularly teachers being diverted by corrupt officials. You have heard of drugs stolen from medical stores and hospitals. Such corrupt practices result in our children not getting education and in patients not getting drugs. Some accidents occur on our roads because of corruption. You see vehicles that are worth dumping still on our roads. How do they get their road licenses? Roads are neglected because of corrupt officials. Investors, later on citizens, complain that they cannot get proper services such as telephone, electricity or water because fixing them often requires that officials have to receive bribes first. In contracts you see an organization opting to buy a more expensive piece of equipment and leaving out an equally effective but cheaper one just because officials concerned with the tender received bribes. In all such cases our people suffer, public funds get wasted, and the rate of social and economic development gets retarded (Inspectorate of Government/Friedrich Eberte Stiftung, 1989).

Tribalism is the act of favoring people of your speech community visa via people from other speech communities and is caused by bad governance. Tribalism is responsible for the political instability and conflict in most African countries evidenced by civil wars and crises in Rwanda, Burundi, Liberia, Ethiopia and Nigeria. The effect of tribalism in Africa has been colossal in terms of death and suffering, poverty, inequalities and regional imbalances, hatred, conflicts, economic loss and under development. The genocide in Rwanda in early 1990s was largely due to tribalism (Tutsi Vs Hutu).

Tribalism has majorly two obnoxious elements: One is prejudice against other tribes, their customs, food, languages, abilities and physical appearances. It further creates arrogance on the part of the large tribal, which is normally oppressive to the smaller tribes, which often breeds hostility and counter hostility. Two, tribalism is closely associated with favoritism in terms of competition for power, property, jobs and development resources. Tribalism blinds people to the truth and justice. Such is very grave in Kenya, one of the arch tribalistic countries in Africa (Kinoti, 1997). No doubt therefore, that the prevalence of disasters and crises in Africa is due to corruption and tribalism, in addition to bad governance.

De-culturation, Ethnocide, and Hegemony are there key issues that continue to perpetuate the dependency syndrome, another major development challenge in Africa. De-culturation is the negative way of affecting the culture/life of another people. Ethnocide is the process of one culture directly or indirectly dominating another, suppressing it, making it inferior, and "killing" it in the long run. Hegemony is the dominance of one group or state or culture over another. No doubt, Africa is suffering from de-culturation, ethnocide, and hegemony due to slave trade, colonialism, racism among others which uprooted African values, called them barbaric, archaic, uncivilized, inferior, satanic and full of evils particularly Christian missionaries who introduced new civilization which was western with many of its aspects unfit in Africa and not sustainable. Furthermore, the western dominance and direction in the cultural, religious, social, economic and political spheres of Africa while underrating her heritage and systems, has greatly contributed to the crises typical of violence of all kinds, inferiority complex, extermination and alienation. Africa's underdevelopment is rooted in the denial or misconception about the humanity of African's backed up by the fact that any development that takes place in another 
culture is not sustainable as it is in Africa (Developments in Africa is a Western concept) hence the disasters and crises.

Africa is in crisis today because of looking at development as universal as if societies are homogeneous and attempts to transplant western view of development into Africa. Development in its simplest meaning is growing and becoming more advanced in the social, economic and political spheres of life. It does not mean photocopying, or growing to resemble the western world. As I write this paper, Africa's development challenges are due to imitating western world like modernization theories, social life styles, methods of work, technologies, education, religion, and development ideologies (capitalism, socialism). Furthermore is the use of western concepts like Gross National Product (GNP), The Composite Social Development Index (CSDI), The Physical Quality of Life Index (PQLI) and The Human Development Index (HDI) to measure African development. Additionally also is the use of Non Government Organization (NGOs) and other development agencies ideas and funds which "kill" innovation and perpetuate dependence in Africa. This is making development a western concept which is wrong and the effects are; dependency, "killed" innovations, low productivity, unemployment, poverty, and environmental degradation.

Development ideologies: Capitalism, Socialism and Communism. Capitalism which is the process of creating wealth using capital succeeded in the Western World (U.S.A, Britain, France, Germany, Canada, and Japan), it is now the ideal for development and African countries are imitating capitalism in their production. Africans have forgotten or they are not aware that the success of capitalism in the Western World was due to contextual geographical and historical factors which are apparently not in Africa. I do not discredit capitalism, but its contextual application in Africa is rather hurried and lacks detailed consultation. No wonder crises like economic instability (ups and downs) being experienced in our economies, inflation and unemployment (particularly companies that are using more of capital intensive technology), neglect of public interests like roads, railways (collapse of East African Railways), education, health, and communication. Policies typical of liberalization, privatization and its nature of being "free enterprise" economy favour a minority at the expense of the majority. Inequalities in the distribution of wealth among regions and people are widening in Africa yet in the original Africa, the inequalities were to a very limited extent.

The Education system in Africa is narrow, shallow, examination oriented, training job seekers rather than job makers, less nationalistic and limited in development skills which is creating catastrophe in Africa. This can most clearly be found in the character and results of the development process itself as Todaro (2000) writes:

After more than three decades of rapidly expanding enrollments and hundreds of billions of dollars of educational expenditure, the plight of the average citizen in many parts of south Asia, Africa and much of Latin America seems little improved. Absolute poverty is chronic and pervasive. Economic disparities between the rich and poor widen with each passing year. Unemployment and underemployment have reached staggering proportions, with the "educated" increasingly swelling the ranks of urban unemployed

Earlier claims made like the one above that education would accelerate economic growth, raise levels of living especially for the poor, generate wide spread and equal employment opportunities for all and reduce ethnic tensions/tribalism are now less of a reality. In fact, education has created more unemployment, poverty, tribalism, corruption, inequalities, segregation, and discrimination, which are creating more disasters and crises in Africa.

Export of raw materials like cotton, coffee, sisal, minerals and timber unprocessed reduces foreign exchange, employment and development of Africa. For example, exporting cotton means that all spinning, yearning, weaving, printing, colouring, and finally making of garments is done by the developed countries thus earning more incomes, taxes, employment and development than Africa where it is grown ( $1 \mathrm{~kg}$ of cotton unprocessed sent to the West generates $\$ 10$ to the West). Imagine how much Africa has lost over centuries, it is uncountable, hence the present crises.

Balkanization of Africa into 56 small states at present with a population less than one country like China is absurd. This has created so many internal conflicts like the great lakes region involving D.R.C, Uganda, Rwanda, Burundi, Zimbabwe, and Zambia among others. Conflicts between Uganda and Rwanda, Uganda and Congo, Uganda and Sudan, Eritrea and Ethiopia and many others have created crises in Africa. Further, such Balkanization led to division of people of the same ethnicity into two countries like the Massai of Kenya and Tanzania, Basamya of Kenya and Uganda to the extent of dividing members of one family into two nationalities like Rev. Can Awori produced children from one wife but some are Kenyans like H.E. Moody Awori former Vice president of Kenya and some are Ugandans like Hon Aggrey Awori former Member of Parliament SamyaBugwe North (1996-2006) and former presidential candidate of Uganda in 2001. Such divisions have created more ethnic wars in the desire for unity and liberation. Furthermore, such balkanization has failed integration of markets, economic cooperation, and negotiation power in international trade hence "tailing" in trade with low achievements.

Africa by 2005 had a population of approximately 830 million people, which constituted about $11 \%$ of the world population. In 2012, the population was estimated at 995 million people and the most recent estimate in 2014 by United Nations Population Fund (UNFPA) puts Africa's population at 1.132 billion people. Africa is $3.1 \mathrm{x}$ bigger than China but China's population is about $1.2 \mathrm{x}$ bigger than that of Africa. Africa is 11 times bigger than India (one state) in size but India has a bigger population than Africa (56 states). Such a low population means low market, low labour force, 
low resource utilization for consumption and production. No wonder, many resources of Africa are idle, underutilized or utilized by foreigners.

It is equally important to note that the African population in its smallness, $50 \%$ of the population is illiterate or semiilliterate thus can supply casual and semi- skilled labour hence being a liability in that context. Further it is composed mainly of young people who cannot work hence perpetuating the dependency syndrome. A case in point is Uganda with the largest number of young people in the world by 2012. In addition to being small, Africa comprises of hundreds of ethnic groups speaking over 800 languages by 1995 . The region is the most heterogeneous (in proportion to its population) in the world, which is a blessing in disguise particularly in causing ethnic conflicts and tribalism leading to corruption and favoritism thus perpetuating underdevelopment.

Additionally, the low population creates limited markets in Africa besides other factors like low income and consumption habits, which are disincentive for local and foreign investments as well as general development. For example, the World Health Organization (W.H.O) requirements for normal consumptions like milk is 210 liters per annum but Africans consume 40 liters per annum on average. Meat is 80 kilograms per annum but people consume $6.3 \mathrm{~kg}$ per annum. Such a huge deficiency in consumption deters investment and development.

Moral decay and separation of ethics from development: Ethics and development are intimately linked. You cannot have one without the other. One of the development crises in Africa is due to this separation. Economic growth, which is part of development, is sometimes promoted to the detriment of human values like displacement of people, high taxes, and ill health or of the environment like pollution and degradation which are now hitting hard Africa and the world at large. For example, half of the forests that originally covered $46 \%$ of the earth's land surface are gone. Desertification and land degradation threaten nearly one quarter of the land surface of the globe. Over 250 million people are directly affected by desertification and 1 billion people are at risk of the same. Global warming is expected to increase the earth's temperature by $3 \mathrm{C}$ (5.4F) in the next 100 years, resulting in multiple adverse effects on the environment and human society including: wide spread species loss, ecosystem damage, flooding of populated human settlements and increased natural disasters. An estimated 40 million people in various parts of the world have been forcibly evicted and displaced from their lands (Nangendo, 2005) because of moral decay and increasing injustice. These are global statistics where Africa is inclusive.

Moral and ethical failure is at the center of the prevailing socio-economic crisis in Africa evident in the selfishness on the part of the developed world and the ruling African elite which has greatly contributed to the prevailing crises. Bad governance, tribalism, corruption, nepotism, dishonesty, laziness, and embezzlement are widespread in African societies because of moral decay. These evils contribute significantly to the development challenges of Africa and account largely for the disasters and crises in the continent.

\section{Conclusions}

It is now clear that Africa's disasters and crises are not natural phenomenon, but social, economic and political constructs rooted in the erosion, denial and in some cases suppression of African cultures, resources and humanity. The causes are largely external, but internally, African's are not blameless. The disasters and crises can be averted through deconstructions of these social, economic and political constructs taking high regard of appropriate solutions from Africans because there can be no meaningful development outside one's culture.

\section{Way Forward/Recommendations}

Africa has enough resources to deal with her challenges provided the historical distortions that have caused disasters and crises in Africa are dealt with legally and ethically. Africa is neither poor nor developing: It is impoverished. Therefore, disasters of Africa are rooted in social, economic and political constructs with a historical context but not inevitable and thus can be averted.

Africans must forgive the colonialists and the historical distortions in order to forge a way forward. In other words, Africans must stop criticizing the colonial activities because there is no solution in criticism and forge a way forward. And I am firm on this position because most Africans (writers or teachers or politicians) spend more than $75 \%$ of the time merely talking or criticizing colonial activities without providing solutions because solutions are not found in criticism but only in dialogue and forging away forward. As Marc De Bodt says: "Worrying is like a rocking chair, it keeps you moving but it gets you nowhere!" Africans must move on and shape their course of development.

Countries, which have hurt Africa, must start off by apologizing. This should be followed with compensation and reparations like for some of the African art found in the museums in the developed countries. Available means and forums should be used and the church should take a central role in forgiving, apologizing and reconciling Africa and the North.

Ethics and Development must be viewed as in inseparable and thus situated in the entire development process as the core value. This will bring about cultural rejuvenation, moral rehabilitation and nationalism/Pan Africanism which now stand out to be the major pre-requisite for African development.

Justice, Ethics, and Moral rehabilitation is needed in Africa. The whites should change their attitudes towards Africans as being inferior to being equals as human beings searching for justice on this planet. Dialogue, in the interest 
of Africa and justice, is what Africa needs not aid. The continent has been humiliated and impoverished through mechanisms presupposed to help it. This must end with establishment of dialogue and justice.

Moral rehabilitation of all people across all institutions like schools, public service, hospitals, industries, families, and communities must start. This might reduce the cancer of corruption, unhealthy competition, tribalism and many unethical practices in pursuance of development, which is responsible for Africa's disasters. Religious institutions should take a leading role in moral rehabilitation and the Government should set up tough sanctions for immoral people with firm implementing agencies.

Africans must know their cultures and history very well, which will serve as a basis for designing educational, economic and political systems relevant to African context. Africans must stop relying on foreign solutions and aid to their challenges. They should remember some of their sayings like "borrowed water does not quench thirst" (In Lusoga, one of the languages in Eastern Uganda, it is rendered thus: "Amadi amasabbe tigawonya ndiwo"). I do not mean to stop completely from borrowing because it is not health but such borrowing should be conditioned to holistic development of Africa. Africans must reject aid, ideas, theories, models, policies and programmes from the west that humiliate and create dependence.

Africa must take stock of and use of its resources in order to end the disasters and exploitations it has undergone. The resources must be studied and theorized in schools in order to come up with economic and political solutions and systems that will exploit them well for the benefit of Africa. Africa must produce a good part of their needs locally in order to break the dependence syndrome from the west. It should develop industries that provide essential inputs to agriculture, process agricultural products and develop small scale industries. Thus applying the balanced growth theory advanced by Hirschman, which is to start with one period, and the rest will follow in the next period because Africa has no capacity to massively invest in every sector in one period as the balanced growth theory suggests. Consequently, integrating fully from the production of raw materials to the local processing and fabrication will be possible thus meaningful and sustainable industrial development will take place relevant for Africa. Therefore, industrial development based on imported basic metals (iron, and steel, copper and aluminum) and basic chemicals (acids, gases, and intermediates), which lead to continued dependency, must be rejected. This will be possible if Africans speak with one voice through the African Union (AU) which will have a bargaining power in the International organizations and be able to regulate trade exchange like the World Trade Organization (WTO).

Africa must identify allies outside the continent who are in for Africa and work together for the good of Africa. Therefore, African institutions like education, health, government, army and civil society like the church must identify similar, related or sympathetic bodies to partner with and dialogue with in the interest of Africa. The assumption here is that not all West is against Africa and not all Africa is in for Africa. In addition to identifying allies, Africa must identify Africans (persons or organizations) against Africa and rebuff/rubbish them as worthless and nonsense. Meetings/conferences where Africans are lectured to and given recipes for their challenges in the end which prolong the suffering of Africans and the continent, must be rejected and protested. In the process/effort of dialogue, exchange and collaboration of whatever level and nature, Africans need to be vigilant with groups, which come with the best intentions of helping but end up reinforcing prejudice against Africans, which leads to underdevelopment instead of development.

The African elite especially the political and religious leaders and the academicians must stop criticizing "Africanism" particularly in favor of "Europeanism". They have no chance of changing from Africa to Europe, therefore they should do research to promote African values. By this statement I do not mean Africanism in totality but partial Africanism, which is good for our development formerly ignored by Europeans and discarded as bad that leads to under development. African leaders and elites should realize that the power they have is for managing society in such a way that each person's dignity is respected and promoted not suppressed and violated. The relevant authorities should put in place severe sanctions for those who abuse office and they must be held accountable. African leaders must ensure good governance and those short of it should be exposed by the people and fellow leaders. Furthermore any cooperation or support locally or internationally should be hinged on the evidence of good governance. This will increase on the accountability of African leaders as well as good governance which is necessary for development.

South-South cooperation, regional and sub regional economic integration is one of the answers to Africans exploitation from the North and economic disorder. Economic integration will enable Africa as a whole and her regions in particular: East, West, Central, South North East and North Africa and other nations of the South to exploit economies of scale, use maximumly their resources, capital, markets, increase on the bargaining power for better prices and engage in better research for development. Africa will be in position to reduce poverty, disease and ignorance, end exploitation from the west and unemployment and thus be able to provide basics needs (food, shelter, clothing, health services, education, and clean water) to her people. Furthermore, such cooperation will reduce the effects of balkanization (conflicts and wars) because of desire to promote economic interests and in the long run "de-balkanization" can start off with countries like the proposed East African Federation (combining Uganda, Kenya, Tanzania, Rwandan and Burundi) hence bringing unity on the continent. African Union should take a leading role in promoting unity.

African Union (AU) should work towards achieving greater unity and solidarity between the African countries 
and the people of Africa. A.U must put in place measures to resolve conflicts, and to prevent more from occurring. AU must put in place sanctions for those who violet peace and democracy as it was in Togo upon the death of the national President early 2005, H.E.Gassingbe Eyadema, when his son took over presidency in a less democratic way, he was forced to resign and general presidential elections were held where he worn democratically. A.U should ensure that the immense resources of Africa are used properly to satisfy the basic needs of all Africans.

Finally, Africa and the West must work together to celebrate their common humanity because the time for exploitation and humiliation is over. As Wade Davis warns us, the western model of development is suicidal. Together we must learn from and evolve an economic, political and social system which satisfies human needs of the present generation without compromising the ability of the future generations from meeting their needs. We must find a way of respecting cultural diversity and differences and end de-culturation, ethnocide, and hegemony. We must respect Africans and if we don't, we shall be doing violence to ourselves because as Malcolmx tells us: in hating Africa and hating Africans, we end up hating ourselves (Kanyandogo, 2002).

Grace and peace from God our Father and Jesus Christ our Lord be with all Africans and those who love Africa.

\section{REFERENCES}

[1] Ayres, R., 1995. Development Studies: An Introduction through Selected Readings. Kent: Greenwich University Press.

[2] Boon, G.C. \& Gopinathan, S., 2006. The Development of Education in Singapore since 1965: Background Paper prepared for the Asia Education Study Tour for African Policy Makers, June 18 - 30, 2006. National Institute of Education, Nanyang Technological University.

[3] De Beer, F. \& Swanpoel, H., 2000. Introduction to Development Studies. Oxford \& New York: Oxford University Press.

[4] Jhingan, M.L, 2003. The Economics of Development and Planning, 36th edition. Mayur Vihar: Vrinda Publications (P) Ltd.

[5] Inspectorate of Government/ Friedrich Ebert Stiftung (IG/FES). 1998. The Crusade against Corruption in Uganda a Collection of Papers. Kampala: Friedrich Ebert Stiftung.

[6] Kanyandago, P., 2002. Anthropological History and Interpreting African History and Culture. Paper Presented to the SORAC 2002 International Conference, November 7-9, 2002. Montclair State University.

[7] Kinoti, G. \& Kimuyu, P., 1997. Vision for a Bright Africa: Facing the Challenge of Development. Kampala \& Nairobi:
African Institute for Scientific Research and Development/International Fellowship of Christian Students.

[8] Kiirya Charles, 1996. Major Themes in African History 1855-1914. Jinja: Local Printers.

[9] Lubaale, G., 2011. Higher Educational Programmes in the Development of a Nation: Cases of Development Studies Programmes of Uganda Martyrs and Makerere University of Uganda. Berlin: Lambert Academic Publishing.

[10] Lubaale, G., 2012. Tertiary Institutions: Theory, Practice and Opportunities. Cases of Makerere, Kyambogo and Uganda Martyrs Universities of Uganda in Delivering Quality Education for Development Berlin: Lambert Academic Publishing.

[11] Mamdani, M., 1999. Politics and Class Formation in Uganda. Kampala: Fountain Publishers Ltd.

[12] Mamdani, M., 2007. Scholars in the Marketplace: The Dilemmas of Neo-Liberal Reform at Makerere University, 1989-2005. Kampala: Fountain Publishers LTD.

[13] Minara Chamber of Commerce., 2015. Other Countries in Africa (56). Accessed from:

http://www.minara.org.za/index.php?option=com_content\& view $=$ article $\&$ id $=89$ :other-countries-in-africa-56\&catid $=1: a b$ out-safrica \&Itemid $=36$.

[14] Nduhukhire, O.M., 2003. Growth and Maldevelopment: Uganda's Experiences. Nkozi: Uganda Martyrs University Press.

[15] Okiira, O.P., Matovu, F. \& Mpuga, P., 2001. A Hand Book of Development Economics. Kampala: The New Vision Printing and Publishing Cooperation.

[16] Rodney, W., 1972. How Europe under developed Africa. London: Bugle-l'ouverture Publications.

[17] Rostow, W.W., 1990. Theorists of Economic Growth from David Home to the Present; with a Perspective on the next century. New York: Oxford University Press.

[18] Tayebwa, B.M.B., 1992. Basic Economics. Kampala: Simplified Textbooks Agency (STA).

[19] Todaro, M.P., 2000. Economic Development. Essex: Pearson Education Limited.

[20] Todaro, M.P., 2006. Economic Development, 9th edition. Essex: Pearson Education Limited.

[21] UNDP., 2005a. Human Development Report 2005: International Cooperation at a Crossroads: Aid, Trade and Security in an Unequal World. New York: Oxford University Press.

[22] UNDP., 2005b. Uganda Human Development Report 2005: Linking Environment to Development: A Deliberate Choice. Kampala: UNDP.

[23] World Atlas., (2015). Africa. Accessed from: http://www.worldatlas.com/webimage/countrys/af.htm.

[24] World Bank/UNESCO., 2000. The Task Force on Higher Education and Society: Higher Education In Developing Countries: Peril And Promise. Washington, DC: World Bank/UNESCO. 